\title{
Remedies for Discrimination: a Comparison of the Draft Common Frame of Reference and the Acquis Principles
}

\author{
Fryderyk Zoll
}

Published online: 20 August 2008

(C) ERA 2008

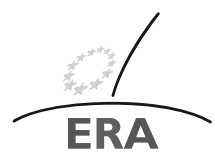

EUROPÄISCHE RECHTSAKADEMIE ACADEMY OF EUROPEAN LAW ACADEMIE DE DROIT EUROPEEN ACCADEMIA DI DIRITTO EUROPEO TRIER - TREVES - TREVIRI

\section{Two Similar Sets of Rules with a Different Concept of Remedies}

Anti-discrimination law forming part of the acquis communautaire by now affects the core of European contract law. Two EC directives (Directives 2000/43/EC and 2004/113/EC) go beyond the boundaries of labour law and govern either exclusively (in the case of Directive 2004/113/EC) or together with other contracts (in the case of Directive 2000/43/EC) contracts that provide access to publicly-available goods or services, including housing. ${ }^{1}$ The Acquis Group ${ }^{2}$ has decided to include the antidiscrimination rules in its Acquis Principles, which are a restatement of European contract law. ${ }^{3}$ The rules of the Acquis-Group on combating discrimination have been taken over (with some modifications) into the text of the Draft Common Frame of Reference. ${ }^{4}$ The differences between the two texts are largely of a technical nature. The main difference seems to be in relation to remedies. The Acquis Principles contain in Article 3:201 (2) an open general formula, ${ }^{5}$ granting the discriminated person the right "to other remedies ${ }^{6}$ which are suitable to undo the consequences of the

\footnotetext{
1) Directive 2000/43/EC of June 2000 implementing the principle of equal treatment between persons irrespective of racial or ethnic origin and Directive 2004/113/EC of 13 December 2004 implementing the principle of equal treatment between men and women in the access to and supply of goods and services.

2) On the aims and methodology of the Acquis Group see: Dannemann [2], pp. XXIII-XXIV and XXVIIIXXIX.

3) Leible/Navas Navarro/Pisuliński/Zoll [4], p. 106, Art. 3:101, No. 2.; See also: Leible [6], p. 84.

4) An Interim Outline Edition of the Draft Common Frame of Reference has been already published: von Bar/Clive/Schulte-Nölke and Beal/Herre/Huet/Schlechtriem/Storme/Swann/Varul/Veneziano/Zoll [10].

5) Leible/Navas Navarro/Pisuliński/Zoll [4], p. 120, Art. 3:201, No. 9.

6) Note that the right to compensation is granted under Article 3:201 (1).
}

Dr. hab. Fryderyk Zoll $(\bowtie)$

Jagiellonen University ul. Bracka 12, 31-005 Krakau, Poland e-mail: fryderyk.zoll@uj.edu.pl

Fryderyk Zoll is Professor at the Jagiellonian University and the L. Koźmiński College of Law. 
discriminating act or prevent further discrimination". According to Article II.-2:104 of the Draft Common Frame the discriminated person may resort to these remedies "without prejudice to any remedy which may be available under Book VI (Noncontractual Liability for Damage caused to another)" for non-performance of an obligation (including damages for an economic and non-economic loss). The Draft Common Frame of Reference does not allow for an application of remedies, which are not strictly determined by law. Thus the list of remedies is closed. The Acquis Principles generally permit a newly-constructed remedy, developed only for application in the specific case, to be applied, if it is "suitable to undo the consequences of the discriminating act or to prevent further discrimination". ${ }^{7}$ It must however meet the requirement of "proportionality to the injury" (Art. 3:202 (2) of the Acquis Principles). ${ }^{8}$ The text of the Acquis Principles on combating discrimination does not refer directly to the right to damages under non-performance rules. Instead it employs autonomously the notion of "compensation" (Art. 3:201 (1) and 3:202 (1)). Such a reference to non-performance rules in case of compensation was however indirectly assumed. ${ }^{9}$ Therefore, the use of the notion of "compensation" instead of "damages" should not be perceived as inherently inconsistent, because, taking into account the limited scope of application of non-pecuniary damages under Art. 8:402 (4), it should stress the different function of this remedy in the case of combating discrimination.

\section{Justifications for the Different Approaches}

The open system of the Acquis Group was adopted in order to ensure that the available remedy would be able to fulfil the function of anti-discrimination law, which is to undo the consequences of the discrimination or to prevent further discrimination. The anti-discrimination directives provide only limited indications of what the system of remedies should look like. ${ }^{10}$ They require only that the dissuasive effect of such remedies needs to be taken into account. ${ }^{11}$ Compensation is the only mandatory remedy required by the directives. ${ }^{12}$

The methodology of the Acquis Group, confined to the idea of a "restatement" of the acquis communautaire, usually runs into difficulty where the European lawmaker refers to the law of the member states on a particular issue. The developing of an 'own' system of remedies would be necessary as a sort of gap-filling step in this situation. In such a case, taking a conservative approach is required to avoid shifting from a 'restatement' approach to a 'best rule' approach. ${ }^{13}$ The silence of the direc-

\footnotetext{
7) Ibid.

8) Leible/Navas Navarro/Pisuliński/Zoll [4], p. 126, Art. 3:202, No. 11.

9) Leible/Navas Navarro/Pisuliński/Zoll [4], p. 120, Art. 3:201, No. 10.

10) Busche [1], p. 160; Lehmann [3], pp. 80-81; Leible [6], p. 84; Leible [5], p. 140; Trzaskowski [9], p. 607.

${ }^{11)}$ Recital 27 and Articles 8 (2) and 14 of the General Sex Discrimination Directive and Recital 26 and Article 15 of the Antiracism Directive.

${ }^{12)}$ It is almost expressly stated in Article 8 (2) of the General Sex Discrimination Directive. See: Lehmann [3], p. 81; Riesenhuber [7], p. 135.

13) The 'best rule approach', which means a formulation of the particularly desirable rules on the basis of the a comparative review, characterises the approach of the Study Group on European Civil Code. The main task of the Acquis Group is to reflect the existing EC contract law: Dannemann [2], pp. XXIV-XXV.
} 
tives on this issue was however not the sole argument for maintaining an open system of remedies. This was also a question of merit. Non-discrimination, which includes also harassment, may occur in very different forms and in very different phases of contractual or pre-contractual relationship. The system adopted by the Acquis Group is based on the assumption that in such case there is a need to provide a flexible system of remedies allowing responses to different and unpredictable forms of the act of discrimination. Although anti-discrimination law in the contractual context encompasses not only pre-contractual but also contractual relationships, the vast majority of cases relating to contract law would be focused on a denial of entry into a contractual relationship - which in fact means the pre-contractual stage. ${ }^{14}$ The remedy of damages (measured in money) might be insufficient to undo the effects of discrimination. ${ }^{15}$ In cases of harassment, traditional contractual remedies might be insufficient too (The question of whether the problem of harassment should be dealt with in contract law is another issue). The flexible approach of the Acquis Principles was highly controversial also within the Acquis Group itself. Some members of the Acquis Group have argued that such an open system of remedies, transferring relatively far-reaching power to judges, may violate the constitutions of some of the member states. ${ }^{16}$ It was probably such considerations which played the major role in the mode of transfer of the Acquis Group's anti-discrimination draft into the Draft Common Frame of Reference, where the catalogue of remedies is determined and closed. The argument of the need for legal certainty and for clear consequences for discriminatory acts has prevailed. This raises however the question of whether the system of remedies for non-performance is sufficient to fulfil its function of being feasible to "undo the effects of discrimination" and to prevent further infringements, and of playing the role of general prevention.

\section{Remedies for Non-performance of the Draft Common Frame of Reference in the Context of Non-Discrimination}

The Draft Common Frame of Reference provides a set of different remedies in the event of non-performance. ${ }^{17}$ These are a right to enforce performance (Art. III.3:301 and Art. III.-3:302), the withholding of performance (III.-3:401), termination (Art. III.-3:501 - Art. III.-3:505), price reduction (Article III.-3:601) and damages and interest (Art. III.-3:701 - Art. III. 3.-3:711). It needs to be considered whether these remedies may be applied in the case of discrimination in contracts that provide access to, or supply of goods or services.

\subsection{Enforcement of Performance}

At first sight it is difficult to imagine the application of the enforcement of performance in the context of combating discrimination. It is quite clear that this remedy has

\footnotetext{
14) Busche [1], p. 159.

${ }^{15)}$ Leible/Navas Navarro/Pisuliński/Zoll [4], p. 126, Art. 3:202, No. 2.

16) Leible/Navas Navarro/Pisuliński/Zoll [4], p. 119, Art. 3:201, No. 7.

${ }^{17)}$ Leible [5], pp. 140-141.
} 
been designed to solve very different problems. In a technical sense, the requirement not to discriminate appears to be (or it gives the impression of being) a duty than an obligation. ${ }^{18}$ The duty not to discriminate is not explained in terms of the creditordebtor relationship. Anti-discrimination law seems to be closer to tort law than to contract law. ${ }^{19}$ The Draft Common Frame of Reference puts the anti-discrimination rules into a contractual context through references in Art. II.-2:104. ${ }^{20}$ This is stressed by Art. III.-1:105, which states that the anti-discrimination rules of Book II apply with appropriate adaptations, to the performance of any obligation to provide access to, or supply goods, services or other benefits which are available to the member of the public, and to the exercise of a right to performance of any such an obligation or the pursuance or defence of any remedy for non-performance of any such obligation and the exercise of a right to terminate any such obligation. This provision should provide clarification of the scope of application of the anti-discrimination rules, stating that also these rules will continue to apply after the lifting of the contractual obligation. This is, however, probably a superfluous provision.

This all means that the enforcement of performance may also exist as a remedy. If this assumption is correct, it would mean that the difference between the open system of remedies of the Acquis Principles and the closed catalogue of remedies in the Draft Common Frame of Reference is not a dramatic one. ${ }^{21}$ The enforcement of the obligation not to discriminate would mean that a person who is discriminated against could compel such behaviour on the part of the discriminating party, as was "suitable to undo the consequences of the discriminating act". The limits to this remedy would arise from Art. III.-3:302 (3) of the Draft Common Frame, which sets limits for specific performance (viz., where this would involve unlawfulness and impossibility, be unreasonably burdensome or expensive, or where the personal character of performance would make it unreasonable to enforce it).

Such an understanding of the enforcement of performance might also permit enforcing the conclusion of the contract, if the other party denied this for discriminatory reasons.

\subsection{Withholding Performance}

The application of the remedy of withholding performance in the context of combating discrimination would probably be rather exceptional, but it is imaginable. Performance-withholding applies, if the other party has not performed his or her reciprocal obligation or there is a reasonable belief that there will be the non-performance by the debtor. ${ }^{22}$ It is not confined merely to a complete failure of performance, but additionally covers improper performance. It is possible to imagine, for instance in case of a tenancy agreement, that an apartment owner harasses a tenant. The owner is

\footnotetext{
18) On the difference between duty and obligation: von Bar/Clive/Schulte-Nölke and Beal/Herre/Huet/ Schlechtriem/Storme/Swann/Varul/Veneziano/Zoll [10], p. 332 and p. 338.

${ }^{19)}$ See also: Zoll [11], p. 94.

${ }^{20)}$ On the integration of the antidiscrimination law into contract law in general see: Schiek/Paddington/ Bell [8], p. 18.

${ }^{21)}$ Leible [5], p. 141.

${ }^{22)}$ See Article III.-3:401 (1) and (2) of the Draft Common Frame. Note that the notion of non-performance means "any failure to perform the obligation" (Article III.-1:101 (3) of the Draft Common Frame.
} 
violating his obligations, and the improper performance involved in the harassment may entitle the tenant to withhold at least partial of his or her payments.

\subsection{Termination}

If during the contractual relationship one party has discriminated (within the scope of application of anti-discrimination rules), the non-performance may be qualified as fundamental in the sense of Article III.-3:502 and consequently it may allow the discriminated person to terminate the contract. The notion of fundamental non-performance is defined in Article III.-3:502 (2). This definition does not directly address the problem of combating discrimination. It can be however argued that if the performance of the obligation is accompanied by discrimination (the most imaginable configuration of this being a long-term contract and harassment), the creditor is substantially deprived of what he was entitled to expect. In the case of a tenancy, if the owner violates the tenant's dignity by creating an intimidating, hostile, degrading, humiliating or offensive environment, this deprives the tenant of the peaceful use of the apartment and amounts consequently to fundamental non-performance, for the peaceful use of the apartment is probably the main expectation of the tenant. In such a situation, the tenant may terminate immediately the contract of tenancy.

\subsection{Price Reduction}

The remedy of price reduction is generalised in the text of the Draft Common Frame of Reference, following on the model of the Principles of European Contract Law. ${ }^{23}$ It is not merely a remedy available in the case of specific kinds of contracts, but rather one which belongs to the general catalogue of remedies. According to Article III.-3:601 (1) of the Draft Common Frame a creditor who accepts a performance not conforming to the terms regulating the obligation may reduce the price. Although, it may appear at first sight absurd to apply such a remedy to combat discrimination, its use may be quite reasonable in this situation. If for (forbidden) discriminatory reason a person obtains an offer concerning goods or services available to the public (including housing) under worse conditions than another person (who does not have the feature on which the discrimination is founded) and he or she has accepted this offer, the fact that it has happened under the discriminatory circumstances would involve a lack of conformity with the terms regulating the obligation. Such a person may resort to the remedy of price reduction - which means the adaptation of the price to a level which would equal the price would usually have been offered, had the discriminatory act not occurred. This can be an extremely efficient remedy in the event of discrimination, due to the fact that very often the discriminated person has to accept the discriminatory offer, because otherwise he or she would be deprived of the necessary goods or services.

\subsection{Damages}

Damages are the most natural remedy for discrimination. In case of non-performance, the Draft Common Frame of Reference allows resort to the damages for "non-

\footnotetext{
${ }^{23)}$ See: Art. 9:301 of the Principles of European Contract Law.
} 
economic loss", which includes pain and suffering and impairment of the quality of life (Article III.-3:701 (3)). In the majority of discrimination cases it will be the only reasonable remedy, and one which is also easily applied in the pre-contractual phase.

\section{The 'Open' Concept of Remedies in the Acquis Principles Vis-à-Vis the Draft Common Frame of Reference}

According to the Acquis Principles a person who is discriminated against on the grounds of sex, ethnic or racial origin is entitled to compensation (Article 3:201 (1) of the Acquis Principles). The Acquis Principles entitle the discriminated person to other remedies "which are suitable to undo the consequences of the discriminating act, or to prevent further discrimination" (Article 3:201 (2) of the Acquis Principles). The compensation may include damages for pecuniary and non-pecuniary losses (Article 3:202). The Acquis Principles also envisage the possibility of claiming damages in respect of non-material loss for non-performance. This remedy has, according to Article 8:402 (4) of the Acquis Principles, a narrower scope of application than the respective provision of the Draft Common Frame of Reference. For its application the Acquis Principles require that the non-performed obligation purported to satisfy a non-pecuniary interest. Such a formulation could be too narrow for anti-discrimination law. Therefore, the right to compensate non-pecuniary damages under Article 3:202 (1) of the Acquis Principles does not impose further limitations regarding the objective of the unperformed obligation.

The main issue arises however from the adoption of the 'open remedies' clause, according to which remedies are to be determined in the individual case. In some cases these will be the same remedies as in case of the Draft Common Frame of Reference. If one bears in mind the possibility of enforcement of performance under the Draft Common Frame, the difference is not great. The Draft Common Frame provides also an 'open system', but this becomes apparent only after an analysis of the available remedies and its adaptation to the field of discrimination. ${ }^{24}$ The system of the Draft Common Frame is however too narrow. If for example a contract has been declared terminated by reason of discrimination, there is no effective remedy, besides damages, to protect a victim. Under the Acquis Principles it will be possible to invalidate the termination, since it is in many cases the only available remedy which can feasibly undo the consequences of the discrimination. ${ }^{25}$

According to the Acquis Principles the discriminated person may also require the conclusion of a contract with him or her. This remedy needs to be balanced with other values, because it involves a considerable infringement of freedom of contract. But in some exceptional cases, it will be the only remedy that is feasible to undo the consequences of the discrimination. ${ }^{26}$

\footnotetext{
24) Leible [5], p. 141.

${ }^{25)}$ Compare: Leible [6], p. 85; Compare for the Polish law: Trzaskowski [9], p. 614.

26) Leible/Navas Navarro/Pisuliński/Zoll [4], p. 119, Art. 3:201, No. 22. Compare however Leible [6], p. 85. See also Trzaskowski [9], pp. 614-615.
} 


\section{Evaluation}

The 'open' system of the Acquis Principles allows the adoption of whatever remedy is effective. The major benefit of the 'closed system' of remedies in the Draft Common Frame of Reference is not evident, because after the necessary adaptation of the remedies (which have to be bent and adjusted) legal certainty will not be better secured. Instead, in many cases the system will not provide a sufficient remedy to achieve the goals of anti-discrimination law. This writer's opinion is that the open clause of the Acquis Principles will not greatly endanger the predictability of the law. The other solutions are not much better in this respect, but they will leave gaps, which will need to be filled by the use of interpretation.

\section{References}

1. Busche, J.: Effektive Rechtsdurchsetzung und Sanktionen, in: Leible/Schlachter, Diskriminierungsschutz durch Privatrecht, Sellier (2006)

2. Dannemann, G.: Consolidating EC Contract Law: An Introduction to the Work of the Acquis Group, in: Research Group on the Existing EC Private Law (Acquis Group), Principles of the Existing EC Private Law (Acquis Principles), Sellier (2007)

3. Lehmann, M.: Diskriminierungsschutz und Vertragsrecht, in: Schulze, New Features in Contract Law, Sellier (2007)

4. Leible, S., Navas Navarro, S., Pisuliński, J., Zoll F., in: Research Group on the Existing EC Private Law (Acquis Group), Principles of the Existing EC Private Law (Acquis Principles), Sellier (2007)

5. Leible, S.: Non-Discrimination, in: Schulze, Common Frame of Reference, Sellier (2008)

6. Leible, S.: Non-discrimination. ERA-Forum, Scripta Iuris Europei, Special Issue, p. 84 (2006)

7. Riesenhuber, K.: Diskriminierungsverbote im Europäischen Privatrecht, in: Leible/Schlachter, Diskriminierungsschutz durch Privatrecht, Sellier (2006)

8. Schiek, D., Paddington, L., Bell, M.: Cases, Materials and Texts on National, Supranational and International Non-Discrimination Law, Hart Publishing (2007)

9. Trzaskowski, J.: Zakaz dyskryminacji w prawie umów (w:) Pazdan/Popiołek/Rott-Pietrzyk/Szpunar, Europeizacja prawa prywatnego, Vol. II, Wolters Kluwer (2008)

10. von Bar, C., Clive, E., Schulte-Nölke, H.: Principles, Definitions and Model Rules of European Private Law. Draft Common Frame of Reference, Sellier (2008)

11. Zoll, F.: Das Antidiskriminierungsrecht in der Acquis Gruppe und die fehlende Umsetzung von Antidiskriminierungsrichtlinien in das polnische Zivilrecht, in: Schulze, New Features in Contract Law, Sellier (2007) 